\title{
Cerrahi menopoza giren genç kadınlarda cinsellik nasıl etkileniyor?
}

\author{
How does surgical menopause affect sexuality in young women?
}

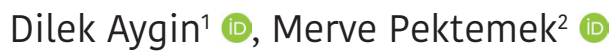

\section{öz}

Menopoz, overlerin fonksiyonlarını yitirmeleriyle birlikte mensturasyonun kalıcı bir şekilde sonlanmasıdır. Menopoz genellikle 45-55 yaşlar arasında görülür, ancak sigara içme, hiç doğum yapmama, toksik kimyasallara maruz kalma gibi birçok faktörün etkisiyle birlikte daha erken yaşlarda da görülebilmektedir. Vücudundaki herhangi bir kanser türü nedeniyle kemoterapi veya radyoterapi tedavileri alan ya da overlerindeki patolojiden dolayı cerrahi tedavi görmüş kişiler cerrahi menopoza girmektedir. Normal menopozdaki gibi menopoza geçiş dönemi bulunmadığından cerrahi menopoz ani olarak gerçekleşir ve etkileri daha ağır görülür. Dolayısıyla, menopozla birlikte vücut bütünlügü değişen kadınlarda hormon düzeylerindeki ani düşüşle birlikte terleme, sıcak basması, cinsel istekte azalma, depresyon, sinirlilik, özgüven kaybı, bellek sorunları gibi problemler daha şiddetli yaşanır. Yaşanan tüm bu sorunların erken tanılanmasıyla birlikte yapılacak olan eğitim-danışmanlık hizmetleri kadının yaşam kalitesini arttıracaktır. Bu derlemede, kanser ve tedavileri nedeniyle cerrahi menopoza giren genç kadınlarda cinselliğin nasıl etkilendiğinin incelenmesi amaçlandı.

Anahtar Kelimeler: Cinsellik, cerrahi menopoz, genç kadın
K adın hayatı kendine özgü fiziksel, hormonal ve psişik farklılıkları bulunan çocukluk, ergenlik, cinsel olgunluk, menopoz ve yaşlılık dönemlerinden oluşmaktadır. Yaşam süresi giderek uzamakta ve menopoz sonrası dönem, kadının yaşam süresinin yaklaşık üçte birini kapsamakta olup, menopoz dönemi ayrı bir öneme sahiptir. ${ }^{[1]}$ Menopoz, toplumsal ve bireysel farklılıklar göstermekle birlikte, genellikle $45-55$ yaş arasında görülmekte olup ${ }^{[2]}$, kadının fizyolojik, mental, kültürel ve cinsel yönden çok fazla etkilenmesine neden olarak yaşam kalitelerini olumsuz yönde

'Sakarya Üniversitesi Sağlık Bilimleri Fakültesi, Cerrahi Hastalıkları Hemşireliği Ana Bilim Dalı, Sakarya

${ }^{2}$ Sakarya Üniversitesi Sağlık Bilimleri Enstitüsü, Cerrahi Hastalıkları Hemşireliği Ana Bilim Dalı, Sakarya

\section{Yazışma Adresi / Correspondence:}

Doç. Dr. Dilek Aygin

Sakarya Üniversitesi Sağlık Bilimleri Fakültesi, Cerrahi Hastalıkları Hemşireliği

Ana Bilim Dalı, Sakarya - Türkiye

Tel. $\quad$ +902642956611

E-mail: daygin@sakarya.edu.tr

Geliş / Received: $\quad 02.10 .2017$

Kabul / Accepted: 13.11.2017

\section{ABSTRACT}

Menopause is, loss of functions of the ovaries and permanent ending of menstruation. Menopause usually occurs between 45-55 years of age, but it can be seen at younger ages with smoking, not giving birth and exposure to toxic chemicals. Some people can get menopause because of they receive chemotherapy or radiotherapy for any type of cancer that occurs in the body and those who have undergone surgical intervention due to the pathology of the ovaries. Surgical menopause is not like normal menopause and it happens suddenly and the effects are more severe. Whereat, sweating with a decrease in hormone levels, hot press, decreased sexual desire, depression, irritability, loss of selfesteem, memory problems are more severe in women who have this type of menopause. The quality of life of the woman will increase with education-counseling to be done after the early identification of such problems. This review aimed to show how sexuality is affected by young women entering surgical menopause.

Keywords: Sexuality, surgical menopause, young woman

etkilemektedir. ${ }^{\left[{ }^{[1]}\right.}$ Menopoz yaşının daha erkene çekilmesi ise bu sorunların daha şiddetli yaşanmasına sebep olabilmektedir. ${ }^{[3]}$ Zayıf, nullipar, sigara içen, kemoterapi gibi toksik kimyasallara maruz kalan kadınların ise menopoza daha erken yaşlarda girdikleri belirtilmektedir. ${ }^{[4]}$

Dünya Sağlık Örgütü (DSÖ) menopozu "ovaryum aktivitesinin yitirilmesi sonucunda mensturasyonun kalıci olarak sonlanması" şeklinde tanımlamaktadır. ${ }^{[2,5]}$ "Patolojik bir neden olmadan 12 ay süreyle menstrual kanamanin olmaması şeklinde görülen menopoza doğal menopoz, patolojik nedenlerden dolayı overlerin alınmast şeklinde görülen menopoza ise cerrahi menopoz" adı verilmektedir. ${ }^{[6]}$

Yirmi birinci yüzyılın temel sağlık sorunlarından birisi olan kanser ${ }^{[7]}$ olguları içinde önemli morbidite ve mortalite sebebi olan ${ }^{[8]}$ jinekolojik kanserler, kadını, ailesini ve toplumun sağlığını etkilemesi bakımından önemli bir yere sahiptir. ${ }^{[9]}$ Histerektomi ve bilateral ooferektomi gibi cerrahi girişimler ve diğer uygulanan tedaviler sonucu cerrahi menopoz gelişen kadınlarda anksiyete, depresyon gibi psikolojik sorunların daha sık yaşandığı, cinsel yaşama 
ilişkin daha fazla olumsuz etkinin görüldüğü, belirtilerin daha şiddetli ortaya çıktığı, beden imajı, benlik saygısında azalma olabildiği vurgulanmaktadır (Tablo 1) $\cdot{ }^{[5-10]}$ Hatta kanser ve tedavilerin en çok cinsel sağlığı etkilediği de öne sürülmektedir. ${ }^{[11]}$ İyatrojenik menopoza radyasyon veya kemoterapi de neden olabilmektedir. ${ }^{[12]}$

$\mathrm{Bu}$ derlemede, kanser ve tedavileri nedeniyle cerrahi menopoza giren genç kadınlarda cinselliğin nasıl etkilendiğinin incelenmesi amaçlandı.

\section{Kemoterapinin kadın cinselliğine etkisi}

Kemoterapötik ajanların türü ve tedavi edilen kanserin tipi ne olursa olsun, kadının cinsel işlevlerinde akut ve/veya kronik sorunlara yol açmaktadır. Kemoterapinin cinsel yaşam üzerindeki etkileri; ilacının tipine, dozuna, kadının yaşına ve tedavi süresine göre değişebilmektedir. Kemoterapi sonrası kadınlarda sıklıkla; cinsel ilgide ve vajinal kayganlıkta azalma, orgazm olamama, disparoni ve cinsel çekicilikte azalma gibi cinsel sorunlar görülebilmektedir. ${ }^{[13]}$ Kemoterapi her iki cinste de istek kaybına ve cinsel ilişki sıklı̆̆ının azalmasına neden olmaktadır. Bu süreçte; bulantı-kusma, yorgunluk, tat-koku değişiklikleri, diyare, konstipasyon, kilo değişiklikleri ve stomatit gibi yan etkiler hasta bireyin kendisini cinsel yönden yetersiz hissetmesine neden olabilmektedir. ${ }^{[14]}$

\section{Radyoterapinin kadın cinselliğine etkisi}

Hastanın genel sağlık durumuna, kanserin türüne ve şiddetine göre intrakaviter (brakiterapi) ya da eksternal radyoterapi uygulanabilmekte ve kadının cinselliğinin, fertilitesinin etkilenmesine neden olabilmektedir. ${ }^{[15]}$ Aslında radyoterapi, cinselliği doğrudan değil çoğu zaman dolaylı olarak etkiler. ${ }^{[14]} \mathrm{Bu}$ olumsuz etkiler özetle; vücut imajında değişiklikler, ağrı, yorgunluk, eşlerin radyoterapi hakkındaki yanlış düşünceleri, over fonksiyonlarının durmasına ve geri dönüşsüz steriliteye neden olması, vajinal lubrikasyonda (kayganlığında) azalmaya bağlı kuruluk ve vajinal kanalda daralmadır. ${ }^{[13,14]}$ Bu olumsuz değişiklikler genellikle radyoterapiden sonraki ilk üç ay içinde ortaya çıkmakta ve bir yıl kadar devam etmektedir. ${ }^{[14]}$

\section{Cerrahi tedavinin kadın cinselliğine etkisi}

Cerrahi uygulanan alan genital organlar veya meme olmasa bile her türlü kanser tedavisi doğrudan ya da dolaylı olarak kadın cinsel fonksiyonlarının etkilenmesine sebep olmak$\operatorname{ta}^{[14]}$, cerrahi girişim sonrasında vücutta yapısal değişiklikler meydana gelmekte, beden imajı, benlik saygısı ve cinsel sağlık bu durumdan olumsuz yönde etkilenmektedir. ${ }^{[11]}$
Tablo 1. Kanser tedavileri, cinsellik, yaşanan sorunlar ${ }^{[10]}$

\begin{tabular}{|c|c|}
\hline Başlıca temalar & Yanitlar \\
\hline $\begin{array}{l}\text { Kemoterapi, } \\
\text { radyoterapi ve } \\
\text { ameliyata bağlı } \\
\text { oluşan semptomlar }\end{array}$ & $\begin{array}{l}\text { - Lubrikasyonda azalma } \\
\text { - Ağrılı cinsel ilişki } \\
\text { - Cinsel istekte azalma } \\
\text { - Orgazm bozukluğu } \\
\text { - Cinsel doyumda azalma } \\
\text { - Cinsel birleşmeden sonra gaz oluşması } \\
\text { - Cinsel temastan kaçınma } \\
\text { - Anorgazmi } \\
\text { - Cinsel yaşamdan memnuniyetsizlik }\end{array}$ \\
\hline $\begin{array}{l}\text { Cerrahi menopoza } \\
\text { bağlı semptomlar }\end{array}$ & $\begin{array}{l}\text { - Sicak basması } \\
\text { - Terleme } \\
\text { - Halsizlik } \\
\text { - Gaz sancısı } \\
\text { - Atrofi } \\
\text { - Kuruluk } \\
\text { - Kötü hissetme } \\
\text { - Huzursuzluk } \\
\text { - Çabuk sinirlenme } \\
\text { - Mutsuzluk }\end{array}$ \\
\hline $\begin{array}{l}\text { Beden imgesinde } \\
\text { değişme }\end{array}$ & $\begin{array}{l}\text { - Kilo alma } \\
\text { - Üreme kaybı } \\
\text { - Kadınlık duygusunda azalma } \\
\text { - İnsizyon yerine bağlı rahatsızık ve ağrı } \\
\text { - Fiziksel güç olarak tükenmiş hissetmek } \\
\text { - Vajinal kısalma } \\
\text { - Vajinal daralma } \\
\text { - Saç, kirpik ve vücuttaki diğer kılların } \\
\text { dökülmesi } \\
\text { - Bulant, kusma }\end{array}$ \\
\hline $\begin{array}{l}\text { Ameliyat sonrası } \\
\text { oluşan sorunlara } \\
\text { bağlı eşin tepkileri }\end{array}$ & $\begin{array}{l}\text { - Cinsel yaşamdan memnuniyetsizlik } \\
\text { - Eşi kaybetme korkusu } \\
\text { - Zarar verme korkusu } \\
\text { - Durumu kabullenme } \\
\text { - Destek olma }\end{array}$ \\
\hline $\begin{array}{l}\text { Ameliyat kabul } \\
\text { etme nedeni }\end{array}$ & $\begin{array}{l}\text { - Ölüm korkusu } \\
\text { - Ameliyat öncesi uzun süren aşırı kanama } \\
\text { - Uzun süren tedaviler } \\
\text { - Çocuklarının olması } \\
\text { - Yaşlandığını düşünme } \\
\text { - Anemiye bağı halsizlik ve yorgunluk }\end{array}$ \\
\hline
\end{tabular}

İleri evre serviks kanserlerinde uygulanan radikal histerektomi, uterusun, overlerin, vajinanın üçte bir üst kısmının, parametriyumun ve lenf nodunun diseksiyonu ile sonuçlanan bir operasyondur. $\mathrm{Bu}$ ameliyat sonrasında, vajina boyunda kısalma, disparoni, vajinal kayganlıkta ve cinsel arzuda azalma gibi postmenopozal belirtiler görülmektedir. Bunun yanı sıra, kadınlarda endometrial karsinoma ve diğer malign olmayan jinekolojik problemlerde, bilateral salpingo ooferektomi ile birlikte total abdominal histerektomi ameliyatı da sıklıkla uygulanmaktadır. Bu ameliyattan sonra da benzer şekilde vajina elastikiyetinde ve kayganlığında azalma gibi sorunlarla sık karşılaşılmaktadır. ${ }^{[13]}$ 
Normal menopoza geçiş sırasında östrojen düzeyi yaşla birlikte giderek azalan kadınların çoğunda vazomotor semptomlar (ateş basması, gece terlemesi, baş dönmesi, baş ağrısı, çarpıntı, nefes darlığı, bulantı), atrofik değişiklikler (vajinal kuruluk, dispepsi, üretral sendrom, ciltte kuruluk, saç dökülmesi) ve psikolojik değişiklikler (anksiyete, depresyon, irritabilite, sinirlilik, uykusuzluk, bellek kaybı, değişken ruh hali, alınganlık, üzücü olayları sık hatırlama, kendini beğenmeme, benlik saygısında azalma, nedensiz ağlamalar, sıkıntı hissi, korku ya da panikler, konsantrasyon eksikliği) ve cinsel işlevlerdeki değişiklikler (vajinal kuruluk, disparoni, uyarılma ve orgazm azlığı, cinsel ilişkiden memnuniyetsizlik) şeklinde istenmeyen semptomların görülmesine neden olmaktadır. ${ }^{[1,4,10,16,17]}$

Cerrahi olarak menopoza girme yaşı, doğal olarak menopoza girme yaşına göre çok düşüktür. ${ }^{[18]}$ Normal menopozda foliküllerin tükenmesi beş-on yılda progresif olarak gerçekleşmekte ve vücut buna kendini hazırlamaya zaman bulmaktadır. Ancak cerrahi menopozda östrojen, progesteron ve androjenlerin eksikliğiyle geçiş dönemi olmadan akut olarak menopoz ve belirtileri doğal menopoza göre daha şiddetli ortaya çıkmaktadır. ${ }^{[12,19,20]}$ Overlerin çıkarılması sonrası serum gonodotropin seviyelerinin artması, androjen miktarının aniden azalmasına yol açmakta ve genellikle cerrahiyi takip eden bir ay içinde klasik menopozal seviyeye ulaşmaktadır. ${ }^{[3,20]}$ Buna uyarılma, cinsel istek, cinsel doyum ve cinsel ilişki sıklığında azalma gibi belirtiler eşlik etmektedir. Özellikle çok genç olan kadınlar cerrahi olarak menopoza girmiş ve bu kadınların hormon tedavisi alması da uygun bulunmamışsa erken menopozun olumsuz etkileri daha ağır olarak seyretmektedir. ${ }^{[3]}$

Gerek doğal gerekse cerrahi menopoza giren kadınların biyo-psikososyal yönden nasıl etkilendiğinin araştırıldığı çalışmalara bakıldığında: Özkan ve Alataş cinsel ilişki sıklı̆̆ının menopoz sonrası dönemde anlamlı şekilde azaldığını, menopoz öncesi dönemde kadınların \%73'ünün haftada bir veya iki kez cinsel ilişkiye girerken, menopoz sonrası bu sıklığın \%42'lere düştüğünü belirtmiştir. ${ }^{[21]}$ Varma ve arkadaşları, hem doğal hem de cerrahi menopoza giren kadınlarda hafif şiddette depresyon ve anksiyete ile cinsel doyum sorunlarının ortaya çıktı̆̆ını, cerrahi menopoza giren kadınlarda cinsel doyumun psikolojik değişkenlerden daha fazla etkilendiğini göstermiştir. ${ }^{[5]}$ Ayrıca cerrahi menopoz sonucu hormon seviyesindeki ani düşüşün şiddetli ruh hali değişikliklerine sebep olduğu ve depresyonun daha kolay gelişebileceği de bildirilmiştir. ${ }^{[22]}$ Menopoz dönemindeki kadınların hormon profilinin depresif belirteçler ile ilişkisi inceleyen Alpay ve arkadaşları, kadınların \%49,7'sinde hafif derecede depresyon, \%18,7'sinde orta derecede depresyon, $\% 65,5$ 'inde minör anksiyete, \%23’ünde majör anksiyete saptamışlardır. ${ }^{[23]}$
Menopoz semptomlarının yaşam kalitesini etkilediği, iyileşmeye yönelik her kadının bireysel ve kendi sağlık durumuna göre değerlendirilmesinin gerekliliği bilinmektedir. ${ }^{[24]}$ Beklenenden daha erken yaşlarda cerrahi menopozun gerçekleşmesi kadınlarda; sağlıklı bir organın çıkarılması, ameliyat ve komplikasyonlarından korkma, ağrı, beden imajı değişiklikleri, doğum yapamama ve kadınsılık özelliklerin kaybı şeklinde algıların oluşmasına neden olmakta ve yaşam kalitesini olumsuz yönde etkilemektedir. ${ }^{[5]}$ Cheng ve arkadaşları tarafından, yaş, eğitim, menopoz durumu ve vazomotor semptomların yaşam kalitesini olumsuz yönde etkilediğini belirlenmiştir. ${ }^{[25]}$ Erkin ve arkadaşları, altı ay ila bir yıl içinde menopoza girmiş olan kadınların yaşam kalitesi puanlarının diğer menopozdaki kadınlardan daha yüksek olduğunu bildirmiştir. ${ }^{[26]}$

Çalışkan ve arkadaşları çalışmalarında, cerrahi menopozun anorgazmi riskini artırdığı vurgulanmış olup, vazomotor semptomların varlığı ve evli kalınan süre arttıkça eşler arasında iletişimsizliğe yol açtığı, spontan, cerrahi ve prematür menopozun ise cinsel ilişki sıklı̆ğında azalmaya neden olduğu tespit edilmiştir. ${ }^{[27]}$ Çelik ve arkadaşları, menopozal semptomlar ve etkileyen faktörler ile ilgili yaptıkları bir çalışmada, kadınların tüm menopoz semptomlarını "orta" ya da "orta düzeye" yakın şiddette yaşadığını belirtmişlerdir. Evlenme yaşı 20 ve üzerinde olan ve ailede kararlara katılan kadınların menopozal semptomları daha az yaşadığı, gebelik sayısı altı ve üzeri olan, cerrahi yolla menopoza giren ve menopozu "yaşlandiğını hissetme", "cinselliğin azalması/bitmesi" olarak algılayan kadınların menopozal semptomları daha fazla yaşadığı belirlenmiştir. ${ }^{[28]}$ Bilge ve arkadaşlarının çalışmalarında, cerrahi menopoz sonrası kadınlarda en sık vajinal kuruluk, cinsel istekte azalma, kilo alma ve ilişki sırasında ağrı sıkıntısı yaşadıkları görülmüştür. ${ }^{[10]}$

\section{SONUC}

Sonuç olarak; cerrahi menopozda yaşanan tüm sorunların erken tanılanması, eğitim/danışmanlık hizmetlerinin planlanması ve tedavisinin etkin bir şekilde yapılması, biyo-psikososyal açıdan kadının iyilik halini arttıracak, cinsel yaşam kalitesini olumsuz yönde etkileyen sorunlarla baş edebilmesini kolaylaştıracaktır.

\section{Hakem Değerlendirmesi}

Dış bağımsız

\section{Çıkar Çatışması}

Yazarlar çıkar ilişkisi olmadığını beyan etmişlerdir.

Peer-review

Externally peer-reviewed.

\section{Conflict of Interest}

No conflict of interest was declared by the authors. 


\section{KAYNAKLAR}

1. Ertekin Pınar Ş, Yıldırım G, Duran Aksoy Ö, Cesur B. Kadına özgü bir sorun: Menopozda ruh sağlığı. International Journal of Human Sciences 2015;12:787-98.

2. Özcan H, Kızılkaya Beji N. Menopoz döneminde cinsellik. Androloji Bülteni 2014;58:209-11.

3. Demirel Bozkurt Ö, Sevil Ü. Menopoz ve cinsel yaşam. Celal Bayar Üniversitesi Sağlık Bilimleri Enstitüsü Dergisi 2016;3:53.

4. Kal HE. Menopozal dönemlerdeki kadınlarda uyku sorunları ve ilişkili faktörler (yüksek lisans tezi). Konya; 2011.

5. Varma GS, Oğuzhanoğlu NK, Karadağ F, Özdel O, Amuk T. Doğal ve cerrahi menopozda depresyon ve anksiyete düzeyleri ile cinsel doyum arasındaki ilişki. Klinik Psikiyatri 2005;8:109-15.

6. Uludağ A, Çakır Güngör AN, Gencer M, Şahin EM, Coşar E. Kadınların hayatındaki başka bir dönem: Menopoz ve menopozun yaşam kalitesine etkisi. Türkiye Aile Hekimliği Dergisi 2014;18:25_ 30. doi: 10.2399/tahd.14.38415

7. Bag B. Kanser hastalarında uzun dönemde görülen psikososyal sorunlar. Psikiyatride Güncel Yaklaşımlar 2013;5:109-26. doi: $10.5455 /$ cap. 20130508

8. Cancer. http://www.who.int/cancer/en/ (Erişim tarihi:31.10.2016)

9. Uçar T, Bekar M. Türkiye'de ve dünyada jinekolojik kanserler. Türk Jinekolojik Onkoloji Dergisi 2010;13:55-60.

10. Bilge Ç, Kaydırak MM, Aslan E. Jinekolojik kanserin cinsel yaşam üzerindeki etkileri. SDÜ Sağlık Bilimleri Enstitüsü Dergisi 2016;7:31-8

11. Pınar G. Kanser tedavisi alan hastalarda cinsel disfonksiyon ve danışmanlığa ilişkin hemşirelik yaklaşımları. Gülhane Tıp Dergisi 2010;52:241-7.

12. Aslan Erdoğan Ç. Cerrahi menopozun metabolik parametreler (insülin direnci, lipid profili ve karaciğer enzimleri) üzerine etkileri (uzmanlık tezi). İstanbul; 2009.

13. Reis N. Jinekolojik kanser ve tedavilerinin kadın cinsel sağlığına etkileri. C. Ü. Hemşirelik Yüksek Okulu Dergisi 2003;7:35-40.

14. Dinçer Y, Oskay Ü. Kanser ve cinsellik. Androloji Bülteni 2017;63:311-4.

15. Irmak P, Oskay Ü. Jinekolojik kanserlerde uygulanan pelvik radyoterapinin cinsel yaşama etkisi ve hemşirelik yaklaşımı rolü. Androloji Bülteni 2013;55:279-83.

16. Oğurlu N. Kadınların menopozal yakınmaları ve baş etme yöntemlerinin incelenmesi (yüksek lisans tezi). Aydın; 2008.
17. Nappi RE, Albani F, Santamaria V, Tonani S, Martini E, Terreno $\mathrm{E}$, et al. Menopause and sexual desire: the role of testosterone. Menopause International 2010;16: 162-8. doi: 10.1258/ mi.2010.010041

18. Topçuoğlu A, Koç Ö, Duran B, Dönmez M. Cerrahi ve doğal yolla menopoza giren kadınların anksiyete ve depresyon açısından karşılaştırılması. Şişli Etfal Hastanesi Tip Bülteni 2009;43:89-92.

19. Fakılı FE. Menopoza girmiş kadınların beslenme durumları ile fiziksel aktivite ve beslenme bilgi düzeylerinin belirlenmesi (yüksek lisans tezi). Ankara; 2013.

20. Akdağlı S, Tekin M, Özdamar Oİ, Acar G. Cerrahi menopoz sonrası nazal fizyolojide oluşan değişikliklerin anterior rinoskopi ve anterior rinomanometri ile değerlendirilmesi. Göztepe Tıp Dergisi 2011;26:69-77. doi:10.5222/J.GOZTEPETRH.2011.069

21. Özkan S, Alataş E. Menopoz döneminde cinsellik. Türk Fertilite Dergisi 2004;12:370-5.

22. Taylor M. Psychological consequences of surgical menopause. J Reprod Med 2001;46:317-24.

23. Alpay N, Kıvanç ZE, Ulaşoğlu C. Menopoz dönemindeki kadınlarda hormon profilinin depresif belirtiler ile ilișkisi. Düşünen Adam The Journal of Psychiatry and Neurological Sciences 2013;26:171-6. doi: 10.5350/DAJPN2013260207

24. Greenblum CA, Rowe MA, Neff DF, Greenblum JS. Midlife women: symptoms associated with menopausal transition and early postmenopause and quality of life. Menopause 2013;20:227. doi: $10.1097 /$ gme.0b013e31825a2a91

25. Cheng MH, Lee SJ, Wang SJ, Wand PH, Fuh JL. Does menopausal transition affect the quality of life? A longitudinal study of middleaged women in Kinmen. Menopause 2007;14:885-90. doi: 10.1097/GME.0b013e3180333a58

26. Erkin Ö, Ardahan M, Kert A. Menopoz döneminin kadınların yaşam kalitesine etkisi. Gümüşhane Üniversitesi Sağlık Bilimleri Dergisi 2014;3:1095-113.

27. Çalışkan E, Çorakçı A, Doğer E, Coşkun E, Özeren S, Çorapçıŏlu A. Türk kadınlarının menopoza geçiş ile menopoz döneminde cinsel fonksiyonlarının ve yașam kalitesinin kesitsel olarak değerlendirilmesi. Türkiye Klinikleri J Med Sci 2010;30:1517-23. doi: 10.5336/medsci.2008-9799

28. Sis Çelik A, Pasinlioğlu T. Klimakterik dönemdeki kadınların yaşadıkları menopozal semptomlar ve etkileyen faktörler. Hacettepe Üniversitesi Hemşirelik Fakültesi Dergisi 2014; 16-29. 